\title{
PENGARUH KOMPENSASI TERHADAP SEMANGAT KERJA PEGAWAI BADAN PENANGGULANGAN BENCANA DAERAH (BPBD) KOTA BANDAR LAMPUNG
}

\author{
Aji Kulyubi Ganandy ${ }^{(1)}$, Husna Purnama ${ }^{(2)}$, Maria Elina ${ }^{(3)}$ \\ Fakultas Ekonomi Universitas Sang Bumi Ruwa Jurai \\ ajikulyubi_ganandy@gmail.com,husna.purnama@fe.saburai.ac.id,maria.elina@fe.saburai.ac.id
}

\begin{abstract}
Abstrak. Permasalahan dalam penelitian ini adalah kompensasi yang diterima pegawai mengalami keterlambatan dalam hal pembayaran dan kurangnya penghargaan atas peyelesaian pekerjaan mengakibatkan penurunan semangat kerja pegawai. Tujuan penelitian untuk mengetahui pengaruh kompensasi terhadap semangat kerja pegawai Badan Penanggulangan Bencana Daerah (BPBD) kota bandar lampung. Metode penelitian yang digunakan dalam penelitian ini menggunakan metode penelitian deskriptif kualitatif dan kuantitatif . Metode pengumpulan data yang digunakan berupa data primer dan data sekunder. Teknik pengumpulan data yang digunakan adalah observasi, wawancaraa, dokumentasi dan quisioner/ daftar pertanyaan. Teknik sampel akan ditentukan dari jumlah sampel sebanyak 47 pegawai Badan Penanggulangan Bencana Daerah (BPBD) kota bandar lampung. Hasil pengujian hipotesis pengaruh kompensasi (X) terhadap semangat kerja (Y) menunjukan bahwa Nilai $\mathrm{t}$ hitung variabel kompensasi yaitu 3.895 dengan konstanta 4.689 pada $t$ tabel dengan db 47 dan taraf signifikan 0,05 diperoleh 1.678 karena $t$ hitung $>\mathrm{t}$ tabel maka Ha diterima artinya kompensasi berpengaruh positif terhadap semangat kerja pegawai BPBD Kota Bandar Lampung. Kontribusi ( $R$ Square ) sebesar 0.328 artinya sebesar 32,8\% variasi perubahan variabel semangat kerja mampu dijelaskan oleh variabel kompensasi sedangkan sisanya sebesar $67,2 \%$ lagi dijelaskan oleh variabel lain diluar dari variabel penelitian ini.
\end{abstract}

Kata kunci: Kompensasi, Semangat Kerja

\section{PENDAHULUAN}

Peran sumber daya manusia (SDM) dalam organisasi adalah sangat dominan, karena merupakan motor penggerak paling utama di dalam suatu organisasi. Dengan demikian perhatian serius terhadap pengelolaan SDM adalah salah satu faktor penentu keberhasilan organisasi yang mutlak diperlukan.

Berhasil tidaknya suatu organisasi banyak bergantung pada unsur manusia yang melakukan pekerjaan sehingga perlu adanya balas jasa terhadap karyawan sesuai dengan sifat dan keadaannya. Seorang karyawan perlu diperlakukan dengan baik agar karyawan tetap bersemangat dalam bekerja. Pimpinan organiasi dituntut untuk memperlakukan pegawai dengan baik dan memandang mereka sebagai manusia yang mempunyai kebutuhan baik materi maupun non materi serta harus mengetahui, menyadari dan berusaha agar dapat memenuhi kebutuhan pegawainya, sehingga pegawai dapat bekerja sesuai dengan harapan organisasi.

Badan Nasional Penanggulangan Bencana (BNPB) dan Badan Penanggulangan Bencana Daerah (BPBD) dibentuk sesuai dengan amanat UndangUndang Nomor 24 ahun 2007. Sebelum terbentuk BNPB dan BPBD, Satuan Kerja yang bertanggung jawab akan penyelenggaraan dan penanggulangan bencana adalah Badan Koordinasi Nasional Penanganan Bencana (Bakornas PB), akan tetapi setelah terbentuk BNPB Bakornas PB dibubarkan. Berdasarkan Undang-Undang 
Nomor 24 Tahun 2007, fungsi BPBD adalah merumuskan dan menetapkan kebijakan penanggulangan bencana dan penanganan pengungsi dengan bertindak cepat, tepat, efektif dan efisien, termasuk mengkoordinasikan kegiatan penanggulangan bencana secara terencana, terpadu, dan menyeluruh.

BPBD Kota Bandar Lampung dibentuk dan ditetapkan berdasarkan Peraturan Walikota Nomor 47 Tahun 2009 yang kemudian diperbaharui menjadi Peraturan Daerah Nomor 5 tahun 2010 tentang Pembentukan Badan Penanggulangan Bencana Daerah Kota Bandar Lampung dan Peraturan Walikota Nomor 70 tahun 2010 Tentang Tugas, Fungsi dan Tata Kerja Badan Penanggulangan Bencana Daerah Kota Bandar Lampung.

Tugas pokok fungsi BPBD sendiri ialah menetapkan pedoman dan pengarahan terhadap usaha penanggulangan bencana yang mencakup pencegahan bencana, penanganan darurat, rehabilitasi, serta rekontruksi secara adil dan setara, serta sebagai pihak yang mengkoordinasikan kepada satuan kerja perangkat daerah (SKPD) lainnya yang terlibat dalam permasalahan bencana yang terjadi di daerah tersebut.

Berdasarkan uraian di atas, maka dapat diangkat judul "Pengaruh Kompensasi Terhadap Semangat KerjaPegawai Badan

\section{PenanggulanganBencana Daerah} BPBD) Kota Bandar Lampung"

\section{KAJIAN TEORI}

\section{Pengertian Kompensasi}

Masalah kompensasi sensitif karena menjadi pendorong seseorang untuk bekerja juga berpengaruh terhadap moral dan disiplin tenaga kerja. Oleh karena itu, setiap perusahaan/organisasi manapun seharusnya dapat memberikan kompensasi yang seimbang dengan beban kerja yang dipikul tenaga kerja. Berikut ini akan dikemukakan beberapa definisi kompensasi, menurut Siswanto (2003:181) sebagai berikut : "Kompensasi adalah imbalan jasa atau balas jasa yang diberikan oleh perusahaan kepada para tenaga kerja, karena tenaga kerja tersebut telah memberikan sumbangan tenaga dan pikiran demi kemajuan perusahaan guna mencapai tujuan yang telah ditetapkan". Sedangkan menurut Hasibuan (2003:118) mengatakan bahwa : "kompensasi adalah semua pendapatan yang berbentuk uang, barang langsung atau tidak langsung yang diterima karyawan sebagai imbalan atas jasa yang diberikan kepada perusahaan".

Sedangkan menurut Martoyo (2007:116) "kompensasi adalah pengaturan keseluruhan pemberian balas jasa bagi employers maupun employees baik yang langsung berupa uang (finansial) maupun yang tidak langsung berupa uang (nonfinansial)" Jadi secara umum dapat dikatakan bahwa kompensasi merupakan suatu balas jasa dari perusahaan terhadap karyawan yang berupa gaji, upah maupun fasilitas atau sarana yang dapat meningkatkan semangat kerja karyawan, kesejahteraan karyawan, atas pengorbanan waktu, tenaga, pikiran dan jasa-jasa karyawan yang diberikan kepada perusahaan.

\section{Jenis-jenis Kompensasi}

Mulyadi(2001:419) menggolongkan penghargaan ke dalam dua kelompok, yaitu : Penghargaan intrinsik berupa rasa puas diri yang diperoleh seseorang yang telah berhasil menyelesikan pekerjaannya dengan baik dan telah mencapai sasaran tertentu, misalnya dengan penambahan tanggung jawab, pengayaan pekerjaan (job enrichment) dan usaha lain yang 
meningkatkan harga diri sesorang dan yang mendorong orang untuk menjadi yang terbaik. Penghargaan ekstrinsik terdiri dari kompensasi yang diberikan kepada karyawan baik berupa kompensasi finansial seperti gaji, honorarium dan bonus, penghargaan tidak langsung seperti asuransi kecelakaan, honorarium liburan dan tunjangan masa sakit serta penghargaan nonkeuangan berupa ruang kerja yang memiliki lokasi istimewa, peralatan kantor yang istimewa, tempat parkir khusus, gelar istimewa dan sekretaris pribadi.

\section{Faktor-Faktor yang Mempengaruhi Kompensasi}

Pemberian kompensasi finansial harus diperhatikan bahwa kompensasi finansial dapat mempunyai nilai yang berbeda bagi masing- masing individu yang menerimanya. Hal ini disebabkan karena masing-masing individu memiliki kebutuhan, keinginan, dan pandangan yang berbeda satu sama lainnya. Oleh karena itu dalam menetapkan suatu kebijakan pemberian imbalan terdapat factor-faktor yang harus dipertimbangkan selain factor jumlahnya.

Menurut Ahmad Tohardi (2002:416) Faktor-faktor yang mempengaruhi besar kecilnya kompensasi adalah sebagai berikut:

1. Produktivitas, Pemberian kompensasi melihat besarnya produktivitas yang disumbangkan oleh tenaga kerja (karyawan) kepada pihak organisasi atau perusahaan.

2. Kemampuan untuk membayar secara logis ukuran pemberian kompensasi sangat bergantung kepada kemampuan organisasi atau perusahaan dalam membayar gaji atau upah tenaga kerja.

3. Kesediaan untuk membayar. Berkaitan dengan item dua diatas, maka walaupun organisasi atau perusahaan mampu untuk membayar kompensasi, maka belum tentu organisasi atau perusahaan tersebut mau membayar kompensasi dengan layak dan adil

4. Penawaran dan permintaan tenaga kerja. Penawaran dan permintaan tenaga kerja cukup berpengaruh terhadap pemberian kompensasi. Jika permintaan tenaga kerja banyak oleh perusahaan, maka kompensasi cenderung tinggi, demikian sebaliknya jika penawaran tenaga kerja ke organisasi atau perusahaan banyak (over supply), maka pembayaran kompensasi cenderung menurun (rendah).

5. Organisasi karyawan, Organisasi tenaga kerja (karyawan) yang ada di organisasi atau perusahaan seperti pekerja akan turut mempengaruhi kebijakan besar kecilnya pemberian kompensasi.

6. Peraturan dan perundang-undangan, Adanya peraturan dan perundangundangan yang ada akan mempengaruhi kebijakan perusahaan dalam pemberian kompensasi, misalnya diberlakukannya pemberian upah minimum regional (UMR).

\section{Pengertian Semangat Kerja}

Menurut Winardi (2004) semangat kerja mengandung pengertian ketiadaan konflik, perasaan senang, penyesuaian pribadi secara baik, dan tingkat keterlibatan ego dalam pekerjaan. Siagian (2002) menyatakan bahwa semangat kerja menunjukkan sejauh mana pegawai bergairah melakukan tugas dan tanggung jawabnya di dalam organisasi. Semangat kerja adalah kesediaan perasaan maupun perilaku yang memungkinkan seseorang bekerja untuk menghasilkan kerja lebih banyak dan lebih baik. Semangat kerja merupakan suasana kerja yang positif yang terdapat dalam suatu organisasi dan terungkap dalam sikap individu maupun kelompok yang mendukung seluruh aspek kerja termasuk didalamnya lingkungan, 
kerja sama dengan orang lain yang secara optimal sesuai dengan kepentingan dan tujuan organisasi .

Semangat kerja digunakan untuk menggambarkan suasana keseluruhan yang dirasakan para pegawai dalam kantor. Apabila pegawai merasa bergairah, bahagia, optimis menggambarkan bahwa pegawai tersebut mempunyai semangat kerja tinggi dan jika pegawai suka membantah, menyakiti hati, kelihatan tidak tenang maka pegawai tersebut mempunyai semangat kerja rendah.

Menurut Nitisemito menyatakan gairah kerja adalah "kesenangan yang mendalam terhadap pekerjaan yang dilakukan". Meskipun semangat kerja tidak mesti disebabkan oleh kegairahan kerja, tetapi kegairahan kerja mempunyai pengaruh yang cukup besar terhadap semangat kerja. Oleh karena itu, antara semangat kerja dan kegairahan kerja sulit dipisahkan.

\section{METODE PENELITIAN}

\section{Objek Penelitian}

Penelitian merupakan kegiatan yang dilakukan untuk mendapatkan kebenaran atau fakta, yang dilakukan dengan mengumpulkan dan menganalisis data secara teliti, jelas, serta sistematis, dan dapat dipertanggungjawabkan atau dapat diuji kebenarannya. Objek penelitian dalam proposal ini adalah kompenasi dan semangat kerja di BPBD Kota Bandar Lampung yang beralamat di jalan Tendeaan Nomor 2 Kecamatan Tanjungkarang Pusat Kota Bandar Lampung. Penelitian dilaksanakan pada bulan April 2018 sampai Juli 2018.

\section{Metode dan Teknik Pengumpulan Data}

Metode atau cara pengumpulan data dalam penelitian ini dilakukan dengan caracara sebagai berikut :

a. Data Primer, yaitu data yang dikumpulkan dan diperoleh dari BPBD Kota Bandar Lampung. Metode ini adalah suatu tinjauan langsung (field research) yang langsung pada objek penelitian dengan mengambil langkah :

1. Observasi, yakni pengamatan langsung pada objek penelitian Interview, yakni melaksanakan wawancara kepada para pegawai yang menjadi objek penelitian.

2. Kuesioner, yakni mengajukan beberapa pertanyaan secara tertulis dengan alternative jawaban yang diajukan.

b. Data Sekunder, yaitu data penunjang yang diperoleh dengan cara mengumpulkan sumber data, baik dari literatur, majalah, buku-buku yang ada hubungannya dengan kepegawaian yang semuanya menunjang penelitian ini.

\section{Sampel dan Populasi}

Menurut Suharsimi Arikunto (2006) sampel adalah sebagian atau wakil populasi yang diteliti. Pengambilan sampel harus dilakukan sedemikian rupa sehingga diperoleh sampel yang benar-benar berfungsi sebagai sampel. Apabila subjek kurang dari 100 orang maka pengambilan sampel semuanya, apabila lebih dari 100 maka diambil $10-15 \%$ atau $20-25 \%$ tergantung dari kemampuan peneliti dilihat dari waktu, tenaga dan dana, sempit luasnya wilayah pengamatan dari setiap subjek, karena hal ini menyangkut banyak sedikitnya dana, besar kecilnya resiko ditanggung oleh peneliti, untuk meneliti yang beresiko besar, sampel yang diambil besar hasilnya akan baik. Berdasarkan pernyataan Arikunto diatas, maka penulis 
mengambil sampel sebanyak 20\% dari 237 pegawai atau sebanyak 47 pegawai.

\section{Metode Analisis Data}

\section{Uji Validitas}

Uji validitas dilakukan dengan membandingkan nilai $r$ hitung (untuk setiap butir pertanyaan dapat dilihat pada kolom corrected item-total correlations), dengan $r$ tabel dengan mencari degree of freedom $(d f)=\mathrm{N}-\mathrm{k}$, dalam hal ini $\mathrm{N}$ adalah jumlah sampel, dan $\mathrm{k}$ adalah jumlah variabel independent penelitian. Jika $r$ hitung $>r$ tabel, dan bernilai positif, maka pernyataan (indikator) tersebut dikatakan valid. Uji Validitas digunakan rumus korelasi Product Moment sebagai berikut.

$$
r_{x y}=\frac{n\left(\sum X Y\right)-\left(\sum X\right)\left(\sum Y\right)}{\sqrt{\left[n\left(\sum X^{2}\right)-\left(\sum X\right)^{2} \mid n\left(\sum Y^{2}\right)-\left(\sum Y\right)^{2}\right]}}
$$

Keterangan:

$\begin{array}{llll}r_{x y} & = & \text { koefisien korelasi suatu } \\ & & \text { butir/item } \\ \mathrm{N} & = & \text { jumlah subyek } \\ \mathrm{X} & = & \text { skor suatu butir/item } \\ \mathrm{Y} & = & \text { skor total (Suharsimi } \\ & & \text { Arikunto, 2002: } 72)\end{array}$

Nilai $r$ kemudian dikonsultasikan dengan $r_{\text {tabel }}\left(r_{\text {kritis }}\right)$. Bila $r_{\text {hitung }}$ dari rumus di atas lebih besar dari $r_{\text {tabel }}$ maka butir tersebut valid, dan sebaliknya.

\section{Uji Reabilitas}

Uji reliabilitas merupakan alat untuk mengukur kehandalan, ketetapan atau keajegan atau konsistensi suatu kuesioner. Suatu kuesioner dikatakan handal jika jawaban responden terhadap butir-butir pertanyaan dalam kuesioner adalah konsisten atau stabil dari waktu ke waktu.
Selain itu untuk menghasilkan kehandalan suatu instrumen atau kuesioner, peneliti haruslah mengajukan pertanyaanpertanyaan yang relevan kepada responden. Dalam menguji reliabilitas digunkaan uji konsistensi internal dengan menggunakan rumus Alpha Cronbach sebagai berikut.

$$
r_{11}=\left[\frac{k}{k-1}\right]\left[1-\frac{\sum \sigma_{b}^{2}}{V_{t}^{2}}\right]
$$

Keterangan:

$r_{11}=$ reliabilitas instrumen

$\mathrm{k}=$ banyaknya butir pertanyaan

$\sum \sigma_{b}^{2}=\quad$ jumlah varian butir/item

$V_{t}^{2}=$ varian total (Suharsimi Arikunto, 2002: 193)

\section{Uji Hipotesis Secara Parsial (Uji t)}

Uji $t$ digunakan untuk menguji signifikansi hubungan antara variabel $\mathrm{X}$ dan $\mathrm{Y}$, apakah variabel $\mathrm{X}$-benar berpengaruh terhadap variabel $\mathrm{Y}$ secara individual atau parsial. Hipotesis yang digunakan dalam pengujian ini adalah:

Ho: Secara parsial tidak ada pengaruh signifikan kompensasi terhadap semangat kerja

Ha: Secara parsial ada pengaruh signifikan kompensasi terhadap semangat kerja.

\section{HASIL DAN PEMBAHASAN}

Uji validitas dilakukan dengan membandingkan nilai $r$ hitung (untuk setiap butir pertanyaan dapat dilihat pada kolom corrected item-total correlations), dengan $r$ tabel dengan mencari degree of freedom $(d f)=\mathrm{N}-\mathrm{k}$, dalam hal ini $\mathrm{N}$ adalah jumlah sampel, dan $\mathrm{k}$ adalah jumlah variabel independent penelitian. Jika $r$ hitung $>r$ 
tabel, dan bernilai positif, maka pernyataan (indikator) tersebut dikatakan valid.

Berdasarkan hasil pengolahan data dengan menggunakan peralatan matematis melalui program SPSS 16.0 diperoleh nilai koefisien korelasi ( $\mathrm{r}$ hitung) untuk masingmasing variabel bahwa nilai korelasi antar skor item dengan skor total item untuk 10 butir pertanyaan, memiliki nilai korelasi yang lebih besar dari pada nilai korelasi $r$ tabel pada taraf signifikan 0,05 dengan derajad kebebasan df $(\mathrm{N}-\mathrm{K}) / 47-2=45$. Dengan demikian dapat disimpulkan bahwa butir-butir soal tersebut seluruhnya valid.

\section{Uji Validitas}

\section{Validitas Kompensasi (X)}

Berdasarkan hasil pengujian validitas dengan aplikasi SPSS rekapitulasi hasil pengujian validitas kompensasi adalah sebagai berikut :

Tabel Validitas Kompensasi

\begin{tabular}{|l|l|l|l|}
\hline No Item test & Nilai $r_{\text {hit }}$ & Nilai $r_{\text {tabel }}$ & Keterangan \\
\hline 1 & 0.699 & 0.632 & Valid \\
\hline 2 & 0.905 & 0.632 & Valid \\
\hline 3 & 0.946 & 0.632 & Valid \\
\hline 4 & 0.891 & 0.632 & Valid \\
\hline 5 & 0.781 & 0.632 & Valid \\
\hline 6 & 0.699 & 0.632 & Valid \\
\hline 7 & 0.781 & 0.632 & Valid \\
\hline 8 & 0.650 & 0.632 & Valid \\
\hline 9 & 0.765 & 0.632 & Valid \\
\hline 10 & 0.921 & 0.632 & Valid \\
\hline
\end{tabular}

Untuk menafsirkan hasil uji validitas, kriteria yang digunakan adalah Jika nilai $r$ hitung $>r$ tabel maka item angket dinyatakan valid. Berdasarkan hasil uji validitas angket kompensasi secara keseluruhan dinyatakan valid.

Validitas Semangat Kerja (Y)

Berdasarkan hasil pengujian validitas dengan aplikasi SPSS rekapitulasi hasil pengujian validitas semangat kerja adalah sebagai berikut :
Tabel Validitas Semangat kerja (Y)

\begin{tabular}{|l|l|l|l|}
\hline Item test & Nilai $\mathrm{r}_{\text {hit }}$ & Nilai $\mathrm{r}_{\text {tabel }}$ & Keterangan \\
\hline 1. & 0.829 & 0.632 & Valid \\
\hline 2. & 0.787 & 0.632 & Valid \\
\hline 3. & 0.872 & 0.632 & Valid \\
\hline 4. & 0.781 & 0.632 & Valid \\
\hline 5. & 0.832 & 0.632 & Valid \\
\hline 6. & 0.832 & 0.632 & Valid \\
\hline 7. & 0.710 & 0.632 & Valid \\
\hline 8. & 0.688 & 0.632 & Valid \\
\hline 9. & 0.861 & 0.632 & Valid \\
\hline 10. & 0.898 & 0.632 & Valid \\
\hline
\end{tabular}

Berdasarkan hasil uji validitas variabel semangat kerja, maka item angket semangat kerja secara keseluruhan dinyatakan valid.

\section{Uji Reliabilitas}

Uji reliabilitas merupakan alat untuk mengukur suatu kuesioner yang merupakan indikator dari variabel atau konstruk. Suatu kuesioner dikatakan reliabel atau handal jika jawaban seseorang terhadap pernyataan adalah konsisten atau stabil dari waktu ke waktu.Metode yang akan digunakan untuk melakukan uji reliabilitas adalah dengan menggunakan SPSS. SPSS memberikan fasilitas untuk mengukur reliabilitas dengan uji statistik Cronbach Alpha. Suatu konstruk atau variabel dikatakan reliabel jika memberikan nilai Cronbach Alpha > 0.60 (Ghozali, 2005).

Dari hasil perhitungan uji reliabilitas terhadap instrumen penelitian variabel kompensasi menunjukkan adanya reliabel (kesesuaian) baik antara item pertanyaan maupun totalitas. Secara rinci diperlihatkan pada tabel berikut

Tabel Hasil Uji Reliabilitas

\begin{tabular}{|l|l|l|}
\hline Variabel & Cronbach Alpha & Status \\
\hline Kompensasi & 0,952 & Reliabel \\
\hline $\begin{array}{l}\text { Produktivitas } \\
\text { Kerja }\end{array}$ & 0,954 & Reliabel \\
\hline
\end{tabular}

Tabel diatas, menunjukkan bahwa cronbach's alpha total untuk variabel kompensasi sebesar $0.952>0,60$, sedangkan cronbach alpha untuk variabel 
semangat kerjas ebesar $0,954>0,60$, jadi dapat dinyatakan bahwa seluruh kuisioner adalah reliabel.

\section{Uji Signifikansi (Uji t)}

Untuk menguji pengaruh kompensasi secara parsial terhadap semangat kerja pegawai BPBD Kota Bandar Lampung, penulis menggunakan uji statistic $\mathrm{t}(\mathrm{uji} \mathrm{t})$. Apabila nilai $\mathrm{t}_{\text {hitung }}>\mathrm{t}$ tabel maka Ho ditolak dan $\mathrm{Ha}$ diterima. Sebaliknya apabila nilai $\mathrm{t}$ htung $<$ nilai $\mathrm{t}$ tabel maka Ho diterima dan Ha ditolak .

Hasil pengujian hipotesis secara parsial dapat dilihat pada tabel berikut ini :

Tabel Hasil Pengujian Parsial Variabel Kompensasi Terhadap Semangat Kerja

\begin{tabular}{|c|c|c|c|c|c|c|}
\hline & & \multicolumn{2}{|c|}{$\begin{array}{l}\text { Unstandardized } \\
\text { Coefficients }\end{array}$} & \multirow{2}{*}{\begin{tabular}{|l|}
$\begin{array}{l}\text { Standardized } \\
\text { Coefficients }\end{array}$ \\
Beta \\
\end{tabular}} & \multirow[b]{2}{*}{$T$} & \multirow[b]{2}{*}{ Sig. } \\
\hline \multicolumn{2}{|c|}{ Model } & B & Std. Error & & & \\
\hline \multirow[t]{2}{*}{1} & (Constant) & 19.581 & 5.028 & & 3.895 & .000 \\
\hline & Kompensasi & .545 & .116 & .573 & 4.689 & .000 \\
\hline
\end{tabular}

Nilai t hitung variabel kompensasi yaitu 3.895 dengan konstanta 4.689 pada t tabel dengan db 47 dan taraf signifikan 0,05 diperoleh 1.678 karena $t$ hitung $>\mathrm{t}$ tabel maka Ha diterima. Signifikasi variabel kompensasi adalah 0.000 yang berarti probabilitas 0.000 , karena probabilitas kurang dari 0,05 maka Ha diterima. artinya kompensasi berpengaruh positif terhadap semangat kerja pegawai BPBD Kota Bandar Lampung.

\section{KESIMPULAN DAN SARAN}

\section{Kesimpulan}

Hasil pengujian hipotesis pengaruh kompensasi (X) terhadap semangat kerja(Y) menunjukan bahwa Nilai $t$ hitung variabel kompensasi yaitu 3.895 dengan konstanta 4.689 pada $\mathrm{t}$ tabel dengan $\mathrm{db} 47$ dan taraf signifikan 0,05 diperoleh 1.678 karena $\mathrm{t}$ hitung $>\mathrm{t}$ tabel maka Ha diterima artinya kompensasi berpengaruh positif terhadap semangat kerja pegawai BPBD Kota Bandar Lampung. Kontribusi ( $R$ Square ) sebesar 0.328 artinya sebesar 32,8 $\%$ variasi perubahan variabel semangat kerja mampu dijelaskan oleh variabel kompensasi sedangkan sisanya sebesar $67,2 \%$ lagi dijelaskan oleh variabel lain diluar dari variabel penelitian ini.

\section{Saran}

1. Hasil jawaban kouisioner terendah variabel kompensasi berada pada pernyataan Tidak menunda-nunda pekerjaan artinya banyak pekerjaan yang tertunda yang diakibatkan dari kompensasi yang diterima pegawai, Pimpinan hendaknya memotivasi pegawai dengan memberikan reward terhadap hasl pekerjaan agar semangat kerja pegawai tetap terjaga

2. Hasil jawaban kouisioner terendah variabel kompensasi berada pada pernyataan Tidak ada mutasi pegawai, hal ini mengidikasikan adanya ketidakpuasan pegawai dalam pelaksanaan pekerjaan, organisasi hendaknya memotivasi pegawai agar semangat dalam bekerja, salah satu motivasi berupa intensitas komunikasi antara atasan dan bawahan sehingga keluhan - keluhan pegawai dapat diakomodir oleh organisasi.

\section{DAFTAR PUSTAKA}

Ahmad Tohardi, 2002. Pemahaman Praktis Manajemen Sumber Daya Manusia, Universitas TanjungPura, Mandar Maju, Bandung.

Anwar, Prabu Mangkunegara, 2004. Manajemen Sumber Daya Manusia. 
Perusahaan Cetak Pertama, Bandung : PT. Remaja Rsodakarya.

Arikunto, Suharsimi, 2006. Prosedur Penelitian: Suatu Pendekatan Praktik, Edisi Revisi, Cetakan Ketigabelas. Jakarta: Penerbit Rineka Cipta.

Hasibuan S.P. Melayu H, 2007 Manajemen Dasar Pengertian Kompensasi, Jakarta : PT. Bumi Aksara.

Hasibuan S.P. Melayu H, 2003. Manajemen Sumber Daya Manusia, Edisi Revisi, Jakarta : PT. Bumi Aksara.

Martoyo Susilo, 2007, Manajemen Sumber Daya Manusia, Yogyakarta : BPFE.

Mulyadi, 2003. Sistem Akuntansi Edisi Tiga. Jakarta : Salemba Empat.

Nitisemito Alex. S, 2005. Manajemen Sumber Daya Manusia, Edisi Kelima, Cetakan Keempat Belas. Jakarta : Ghalia Indonesia.

Nitisemito, Alex. 2001. Manajemen Personalia ( Manajemen Sumber Daya. Manusia ). Kudus: Ghalia Indonesia.

Nopri. 2017. Pengaruh Pelatihan Dan Pengembangan, Terhadap Kinerja Pegawai dengan Kompensasi Sebagai Variabel Pemoderasi Pada Perum DAMRI Di Bandar Lampung.

Rivai, Veithzal, 2008. Manajemen Sumber Daya Manusia Untuk Perusahaan, Jakarta : PT. Raja Grafindo Persada.

Siswanto, 2000. Pengantar Manajemen. Jakarta : PT. Bumi Aksara. 